\title{
Implementation of Indonesia's Foreign Investment Policy in the development of Japan Foreign Direct Investment in Indonesia
}

\author{
Dr. Anton Minardi, S.IP., S.H., M.Ag., M.A. ${ }^{1}$, Putri Irma Maulani² \\ \{abdurrahmananton1975@gmail.com ${ }^{1}$, putrirmamaulani@gmail.com²\} \\ ${ }^{1}$ Lecturer of International Relations Fisip Unpas,Indonesia \\ ${ }^{2}$ Researcher of International Relations Fisip Unpas Majoring in International Relations Faculty \\ Of Social Science and Political Science, Pasundan University, Indonesia
}

\begin{abstract}
The purpose of this study to determine the policy of the Indonesian government in regulating and improving the investment climate in Indonesia. And know the condition of Foreign Direct Investment in Indonesia, especially the development of Japanese investment in Indonesia. From the five largest investors in Indonesia, namely Singapore, Japan, South Korea, China and the United States, Japan is the second largest investor country in Indonesia. Investment, especially foreign direct investment (FDI) can be one of the factors that influence in encouraging economic development of a country, especially Indonesia as a developing country in order to be able to compete for the progress of the Indonesian nation. As much as 87 percent of Japanese investment in Indonesia is realized in the manufacturing sector. The contribution of manufacturing industry sub-sector (automotive) to GDP of nonoil industry sector reached 10.47 percent or the third largest after the food and beverage industry subsector.
\end{abstract}

Keywords: Foreign direct investment, Investment Policy, Japan FDI in Indonesia.

\section{Introduction}

In working for the welfare and prosperity of its people, the economic aspect is one of the most important factors that must be the concern of a country's government. Indonesia is one of the countries in the world that is still developing in terms of its economic, political and security aspects. The development of the era of globalization where the conditions of increasingly widespread interaction between countries and non-states that play an active role as actors of international relations in global activities such as establishing cooperative relations.

If it is referring to the theory of economic growth developed by Robert Solow with a neoclassical approach, capital formation and population growth are factors that significantly influence a country's economic growth. In terms of capital formation, the role of investment both domestic and foreign through foreign direct investment (FDI) can contribute to a country's economic growth. Based on the Law of the Republic of Indonesia Number 25 of 2007, it is explained that investment is all forms of investment activities, both by domestic investors and foreign investors to conduct business in the territory of the Republic of Indonesia.

For Indonesia, in addition to domestic investment, Foreign Direct Investment (Foreign Direct Investment) has a large role in complementing domestic investment needs. FDI increases production capability and becomes a medium for transfer of technology from abroad to the country. In terms of production, FDI can increase the productivity of domestic companies with the transfer of technology brought along with the entry of FDI. The presence of foreign investment in the form of FDI can also increase the competitiveness and superiority of domestic products. Throughout this path of foreign direct investment or investment is a form of long-term capital flows and can be said to be relatively stable against economic turmoil. Indonesia as one of the developing countries in the Southeast Asia region, has the potential of natural resources and large human resources to attract investors to invest in Indonesia.

The presence of foreign investment in a country, especially foreign direct investment, is expected to have a positive impact on development and economic growth. Indonesia as a developing country that prioritizes the establishment of various cooperation with other countries, 
realizes that to improve economic stability is needed to increase the country's competitiveness in attracting foreign investors.

Factors that are taken into consideration for investors in investing their capital in a country are from the factors of natural resources, human resources, political and economic stability of the country to ensure certainty in business, government policies, and ease of licensing. Therefore, the government policy in particular regarding the regulation of foreign investment is one of the main factors to improve the investment climate in Indonesia.

Refers to James E Anderson's statement which reveals that policy is a series of actions that have specific objectives that must be followed and carried out by the actors to solve a problem (a purposeful denial or problem). The policy regarding the entry of foreign direct investment into Indonesia legally starts with Law Number 1 Year 1967 concerning Foreign Investment and Law Number 6 Year 1968 concerning Domestic Investment. The existence of these two legal instruments is expected so that investors, both foreign investors and domestic investors, can invest in Indonesia.

Investment development in Indonesia has fluctuated from time to time which of course can occur due to various factors such as internal factors where the climate of country risk in Indonesia is poor because it has not been able to create a healthy investment climate such as the factors of political instability, security disturbances and also the law so that the attractiveness of investment is weak.

During the New Order period from 1967 to 1997 the number of foreign investment invested by foreign investors reached 190,631.7 billion US dollars with projects financed by 5,699 projects and increasing from year to year. Likewise with domestic investment that began in 1968 until 1997 the number of domestic investment reached Rp119,887.2 with the number of projects financed by 723 projects which were the highest domestic investment in the New Order era. Entering the Reformation era starting from 1998 to 2006 the amount of domestic investment experienced a significant decline of Rp99,082 trilliun as well as foreign investment which decreased by 29.126 billion US dollars.

Various external factors can also influence the flow of investment into Indonesia such as global economic uncertainty, and efforts to attract investment in the external environment are increasingly tight with changes in economic systems in certain countries, such as in 2002 even though the world economy is experiencing growth, but the current foreign capital (PMA) continues to decline. The declining capital flows flow to certain countries such as RRC and Vietnam. The more open changes in the RRC and Vietnam economic systems have made these two countries a major destination for foreign investment flows that flow into the Asian region supported by high domestic market growth, low production costs, and adequate availability of labor.

Investment attractiveness in Indonesia before the economic crisis (1991-1996) was better than Thailand, but in times of crisis and after the economic crisis, the attractiveness of investment declined even below Vietnam where the average decline in FDI in Indonesia was around 60\% of 1998-2000. Similarly, domestic investment also experienced an average decline of around 30\% in the three years after the crisis (1998-2000) compared to three years before the crisis (1995-1997).

Japan is one of the biggest investors since 1967. Japan's cumulative investment value in Indonesia from 1967 to the end of 2000 was $15.5 \%$ of the total foreign investment in Indonesia. Japanese investment is mostly in the manufacturing sector. This means that Japanese investment has a more concrete role and has a direct impact on Indonesia's industrial development.

Starting from the problems that have been described above, related to the policies of the Indonesian government in regulating the investment that enters Indonesia, especially foreign investment, where legal certainty such as policy is one of the main factors that can influence in increasing investment in Indonesia. Indonesia must immediately rise and rebuild the government system and strive to increase economic growth in order to restore and strengthen the Indonesian economy. Therefore, the authors are interested in discussing further about the development of the entry of Foreign direct investment into Indonesia, especially Japanese FDI to Indonesia after the implementation of investment policy became a study entitled Implementation of Indonesia's Foreign Investment Policy in the Development of Japan FDI in Indonesia. 


\section{Research Problem}

The formulation of the problem raised by the writer in this study is:

"What is the implementation of Indonesia's foreign investment policy in the development of Japan Foreign Direct Investment in Indonesia?"

\section{Research Methods}

The method in the study used by the author in this paper is qualitative methods. This research method is descriptive in analyzing a problem based on general information that is equipped with data. Descriptive analysis research method in which this research method aims to describe a phenomenon or event in detail using clear facts which are then processed and analyzed to draw conclusions.

The qualitative method in this study focuses on the Indonesian government's policy of increasing foreign direct investment into Indonesia, with the implementation of the Foreign Direct Investment Law No. 25 of 2007 to improve the investment climate, in this case taking Japanese FDI case studies into Indonesia.

\section{Discussion and Findings}

In International Relations the interaction between countries and non-countries is intertwined based on various factors such as politics, security, socio-cultural and economic. Collaboration in these various aspects is carried out not only to meet the national interests of each country, but also to create a harmonious relationship between countries in the world. Economic cooperation between countries in the world is one of them with investment. Investment is considered as one of the important indicators to boost a country's economy, especially developing countries. Indonesia is a developing country that receives both domestic and foreign investment. Japan is one of the largest investor countries in Indonesia in a long period of time, until now the bilateral relations between the two countries have been intertwined with various collaborations between the two countries.

Seeing from its history that Japan was among the largest investors which ranked second in competing with Singapore, China, South Korea and the United States. In this chapter the writer will explain more deeply about Japanese investment (foreign direct investment) in Indonesia.

\subsection{Conditions of Foreign Direct Investment in Indonesia}

The development of investment in Indonesia went through various periods, beginning in the early days of independence (1945-1965), during the New Order, and the reformation period. At the beginning of independence or during the Old Order (1945-1965), the flow of investment into Indonesia became non-existent because all companies had been nationalized for the national interest. The initial momentum of the flow of investment into Indonesia began during the New Order (1967-1997). This period is marked by the enactment of Law Number 1 of 1967 concerning foreign investment and Law Number 6 of 1968 concerning domestic investment. The existence of these two laws provides an opportunity for foreign and domestic investors to invest in Indonesia.

The main contributing factor to the low investment entering Indonesia is the assumption from investors that Indonesia is a country that is not yet safe in investing because of the unstable internal conditions of the country.

It can be seen from the chart of the development of foreign investment entering Indonesia from 2008 where the renewal of Law Number 25 in 2007 concerning Foreign Investment until 2017 is currently implemented, it is seen that there are fluctuations in the development of foreign investment in Indonesia each year. We know that this unstable development has been caused by various factors, namely internal factors originating from Indonesia itself such as its social, political and economic conditions or external factors triggered by global political and economic stability. 


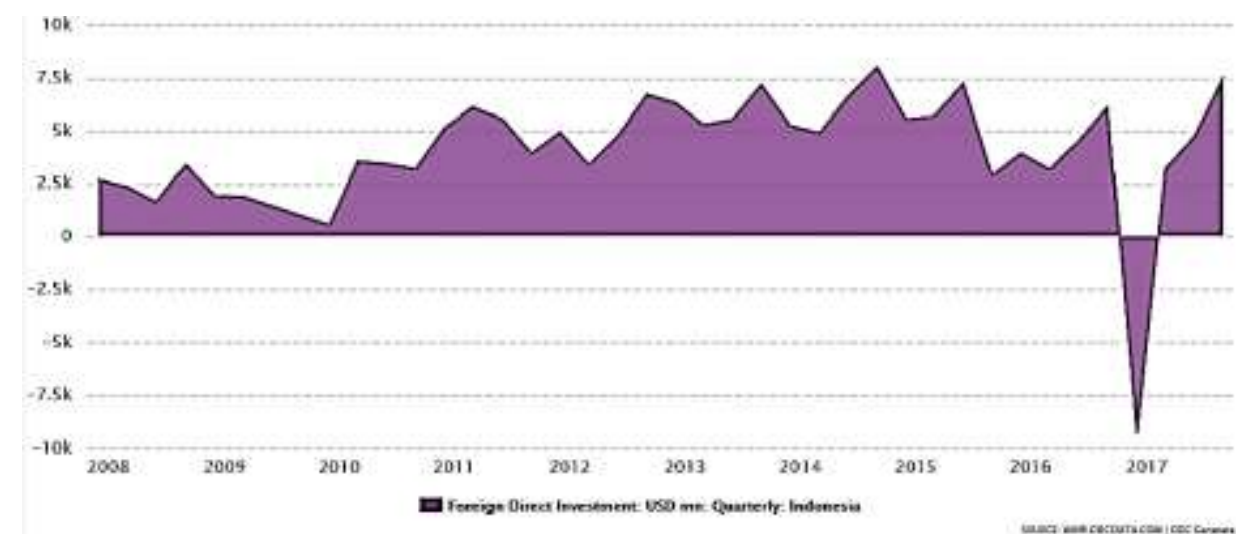

Fig.1. Development of Direct Foreign Investment in Indonesia from 2008 to 2017

The impact of the global economic crisis throughout 2009 affected the flow of foreign capital into direct investment or FDI to Indonesia. Foreign investment (PMA) 2009 fell by Rp 36.45 trillion compared to 2008. The head of the Investment Coordinating Board (BKPM) Gita Wirjawan explained that FDI in 2009 reached Rp 133.83 trillion or US \$14.87 billion, down 27.2 $\%$ compared to 2008 which amounted to Rp 97.38 trillion or US \$ 10.82 billion. While for domestic investment (PMDN) throughout 2009 experienced a sharp increase of $85.7 \%$, from Rp. 20.36 trillion (US \$ 2.26 billion) in 2008 to Rp. 37.8 trillion (US \$ 42 billion) in 2009 .

In total, the amount of direct investment into Indonesia in 2009 was Rp 135.18 trillion or US \$ 15.02 billion, down $12.3 \%$ compared to the total investment in 2008 which amounted to Rp 154.19 trillion or US $\$ 17.13$ billion. The region that brings the biggest investment today is DKI, which was previously the largest investment in West Java. Gita said the number of labor absorption from investments entering Indonesia in 2009 also dropped to 300,682 people from 313,366 in 2008.

Meanwhile, cumulative FDI flows in developed countries fell 27\% last year. This group of countries is said to be the main cause of the weakening of global FDI flows in 2017. The decline in Europe reached 27\% while in the United States (US) it dropped 33\%. Nevertheless, the pressure from the decline in investment flows in the US and Europe was quite helped by a surge in FDI flows in other developed countries, namely Australia which grew 11\%. Meanwhile, the rate of FDI to developing countries recorded moderate growth reaching US \$ 653 billion, up $2 \%$ from the previous year. Capital inflows have increased in Asia, Latin America and the Caribbean, while Africa tends to be flat.

\subsection{Foreign investment policy in increasing FDI to Indonesia}

After it was launched in the era of Susilo Bambang Yudhoyono (SBY) Government through Presidential Regulation No. 97 of 2014 in September 2014, the One Stop Service (PTSP) Center or one stop service at the Investment Coordinating Board (BKPM) office was finally inaugurated by President Joko Widodo on dated January 26, 2015. PTSP is an integrated service in a single process starting from the application stage to the completion of service products through one door. To support the PTSP Implementation, the Development of Electronic Information and Licensing Service System (SPIPISE) is expected to facilitate information and accelerate the investment licensing process. The National Single Window for Investment Portal (NSWI) is an integral and supporting part of SPIPISE which facilitates information needs related to investment feasibility and investment licensing guidelines. Indonesia succeeded in increasing its ranking in the 2016 Ease of Doing Business survey released by the World Bank Group. Referring to the official report of the World Bank Group, Indonesia's position rose 11 positions from the previous 120 rank to 109 th out of a total of 189 countries surveyed. Indonesia is listed as a country that has consistently 
carried out EODB reforms since 2007 so that it is among the top 24 countries that have reformed in three or more indicators. Head of the Investment Coordinating Board (BKPM) Franky Sibarani explained the World Bank Group survey used data in the period between second June, 2014 to first June, 2015. During this period the World Bank recorded positive improvements in three indicators, namely starting a business, accessing credit, and pay taxes. Head of BKPM Franky Sibarany is optimistic that the investment target in 2015 will reach Rp519.5 trillion or grow by around 14 percent from the previous year's achievement.

\subsection{Development of Japan Foreign Direct Investment in Indonesia}

Japan is one of the biggest investors since 1967. Japan's cumulative investment value in Indonesia from 1967 to the end of 2000 was $15.5 \%$ of the total foreign investment in Indonesia. Japanese investment is mostly in the manufacturing sector. This means that Japanese investment has a more concrete role and has a direct impact on Indonesia's industrial development. Diplomatic relations like this, are not something that can be built in just one day. In Indonesia there are around 11,000 Japanese, whereas in Japan there are more than 24,000 Indonesians. Japanese companies operating in Indonesia number more than 1,000 companies, where 300,000 Indonesians work.

\section{PMA}

\begin{tabular}{|l|r|r|}
\hline & Proyek & Investasi US\$. Ribu \\
\hline Singapura & 18,088 & $59,487,201$ \\
\hline Jepang & 11,506 & $27,812,922.3$ \\
\hline Korea Selatan & 11,352 & $12,666,559.6$ \\
\hline Amerika Serikat & 2,081 & $11,821,565.9$ \\
\hline R.R. Tiongkok & 5,692 & $8,396,452.6$ \\
\hline Total & $\mathbf{4 8 , 7 1 9}$ & $\mathbf{1 2 0 , 1 8 4 , 7 0 1 . 4}$ \\
\hline
\end{tabular}

Fig. 2. Rating of Realization of Foreign Investment by Country From 2007 to 2017

From the table above it can be seen that Japan is one of the largest investor countries with the second rank reviewed from 2007 to 2017 with an investment of US \$ 27.8 million. Japan's investment value is the largest of the five largest investors in Indonesia, namely South Korea, the United States, China and Singapore. Bilateral economic cooperation relations have been established for more than half a century, and during that time, Japan played a role in encouraging Indonesia's economic development. Japan also contributes in the fields of trade, investment and technical cooperation, especially the industrial sector in Indonesia. The automotive industry is one of the mainstay sectors whose development continues to be prioritized because it plays a major role in national economic growth. Moreover, Indonesia is still the main destination for investment in the automotive industry sector.

\begin{tabular}{|c|c|c|c|c|c|c|c|c|c|c|c|}
\hline & & \multicolumn{2}{|c|}{2007} & \multicolumn{2}{|r|}{2008} & \multicolumn{2}{|c|}{2009} & \multicolumn{2}{|c|}{2010} & \multicolumn{2}{|r|}{2011} \\
\hline & & Proyek & $\begin{array}{l}\text { Investasi } \\
\text { (US5.: } \\
\text { Ribu) }\end{array}$ & Provek & $\begin{array}{c}\text { Investass } \\
\text { (USs. Ritu) }\end{array}$ & Proyek & $\begin{array}{l}\text { Investass } \\
\text { (US5. } \\
\text { Ribta) }\end{array}$ & Proyed & $\begin{array}{l}\text { Investasi } \\
\text { (US5. } \\
\text { Ribu) }\end{array}$ & Proyek & $\begin{array}{l}\text { Investasi } \\
\text { (USS. Ribu) }\end{array}$ \\
\hline \multirow[t]{2}{*}{ Asia / Asria } & Jepang / Jepan & 114 & $626,366.1$ & 127 & $1,099,610,6$ & 129 & $708,762.6$ & 321 & 712,599 & 353 & 1,515,063:1 \\
\hline & $\begin{array}{l}\text { Total Asia / } \\
\text { Asia }\end{array}$ & 114 & $626,866.1$ & 127 & $1,099,610.6$ & 129 & $708,762.6$ & 321 & 712,599 & 353 & $1,516,063.1$ \\
\hline \multicolumn{2}{|l|}{ Total } & 114 & $626,866.1$ & 127 & $1,099,610.6$ & 129 & $708,762.6$ & 321 & 712,599 & 353 & $1,516,063,1$ \\
\hline
\end{tabular}




\begin{tabular}{|c|c|c|c|c|c|c|c|c|c|c|c|}
\hline \multicolumn{2}{|r|}{2012} & \multicolumn{2}{|c|}{2013} & \multicolumn{2}{|r|}{2014} & \multicolumn{2}{|c|}{2015} & \multicolumn{2}{|r|}{2016} & \multicolumn{2}{|r|}{2017} \\
\hline Proyek & $\begin{array}{l}\text { Imvestasi } \\
\text { (US\$. Ribu) }\end{array}$ & Proyek & $\begin{array}{l}\text { Investasi } \\
\text { (USS. } \\
\text { Ribu) }\end{array}$ & Proyek & $\begin{array}{l}\text { Investasi } \\
\text { (US\$. Ritu) }\end{array}$ & Proyek & $\begin{array}{l}\text { Investasi } \\
\text { (US\$. Ribu) }\end{array}$ & Proyek & $\begin{array}{l}\text { Investasi } \\
\text { (US\$. Ribu) }\end{array}$ & Proyek & $\begin{array}{l}\text { Investasi } \\
\text { (US\$. Ribu) }\end{array}$ \\
\hline 405 & $2,456,940,9$ & 958 & $4,712,894$ & 1,010 & $2,705,131.3$ & 2,030 & $2,375,990.1$ & 2,413 & $5,400,906.4$ & 3,262 & $4,996,158.2$ \\
\hline 405 & $2,456,940.9$ & 958 & $4,712,894$ & 1,010 & $2,705,131.3$ & 2,030 & $2,876,990.1$ & 2,413 & $5,400,906.4$ & 3,262 & $4,996,158.2$ \\
\hline 405 & $2,456,940.9$ & 958 & $4,712,894$ & 1,010 & $2,705,131.3$ & 2,030 & $2,876,990.1$ & 2,413 & $5,400,906.4$ & 3,262 & $4,996,158.2$ \\
\hline
\end{tabular}

Fig. 3. Development of Foreign Direct Investment Realization Based on Country from 2007 to 2017

Japan is the second largest foreign investor in Indonesia with a total investment of US \$ 27 billion in 2017. The automotive, electronics and food and beverage industry sectors have contributed more than 50 percent of Japan's total investment in Indonesia in 2017. Recorded, there were more than 1,750 Japanese companies in Indonesia with business activities in manufacturing, infrastructure and services. Sectors whose investments continue to increase are automotive, metals, machinery and electronics. The Director General of the Development of the Industrial Area of the Ministry of Industry Imam Haryono also promoted the industrial area of Indonesia to Japan. New industrial zones are offered, including Java, namely Karawang, Bekasi, Majalengka, Tangerang and Sidoarjo. For industrial areas outside Java are Ketapang, Penajam Paser Utara, Deli Serdang, Simalungun, Muaro Jambi, and North Gorontalo.

Among the industrial sectors, Japan's highest investment in Indonesia is the Motor Vehicle Industry \& the Transportation and Metal Industry Equipment with an investment of USD 880.6 million, and the Machinery \& Electronic Industry with an investment of USD 384.5 million. Minister of Industry Saleh Husin also mentioned, positive assessments and commitments of Japanese entrepreneurs in accordance with the results of the 2014 ASEAN Business Outlook Survey which placed Indonesia as the most attractive country for business expansion, surpassing Vietnam and Thailand. Regarding the industrial sector, Japan's highest investment in Indonesia is the motor vehicle \& transportation equipment and metal industry with an investment of USD 880.6 million, and the Machinery \& Electronic Industry with an investment of USD 384.5 million.

The Minister of Industry expects that Japanese investors will continue to expand their business in Indonesia, therefore the Indonesian government continues to strive to create a conducive investment climate, among others by providing licensing facilities through the Central One-Stop Service (PTSP) at BKPM. With an economic growth of USD 846 billion and a population of 240 million, Indonesia is the largest economy and market in Southeast Asia. Economic expansion in the future is expected to achieve more significant growth given that GDP per capita is expected to grow four-fold by 2020. The automotive industry in Indonesia is one of the mainstay sectors of the government because it has a big role in the growth of the economy. According to Harjanto's Director General of Metal, Machinery, Transportation Equipment and Electronics (ILMATE), the automotive industry is classified as labor-intensive and has opened up great opportunities for local employment. The automotive industry will continue to be encouraged so as to provide an even greater contribution to the national economy. He added that national economic growth above 5\% is a distinct advantage for Indonesia's automotive industry sector amid the global economic slowdown. According to Airlangga, PT Mitsubishi Motor Krama Yudha Indonesia (MMKI) which was inaugurated in the Greenland International Center (GCII), Cikarang Pusat, West Java Province has a total investment of Rp. 7.5 trilliun with a production capacity of 160 thousand units / year and absorbs energy and workers as many as three thousand people.

\section{Conclusions}

First, Indonesia's policy regarding foreign investment which is used as a reference in regulating the provisions of investment entering Indonesia is stipulated in the law, namely Law Number 25 of 2007 concerning Investment. And through the Presidential Regulation No. 97 of 2014 in September 2014, the One-Stop Integrated Service (PTSP) Center or one-stop service at the office 
of the Investment Coordinating Board (BKPM). Both legal instruments are expected to be an attraction for investors both foreign investors and domestic investors to invest in Indonesia.

If there are legal legality and simplification in the bureaucracy of investment licensing, foreign and domestic investors are interested in investing in Indonesia. So that the investment climate in Indonesia from 2007 to 2017 can be said to improve, despite the fluctuations that are influenced by various factors not only internally, but external factors also have a big influence, such as global economic stability in 2008-2009 and 2017.

Secondly, bilateral economic cooperation has been established for more than half a century, and during that time, Japan played a role in encouraging Indonesia's economic development. Japan is one of the largest investors since 1967. Japan's cumulative investment value in Indonesia is 10.2 percent of total foreign investment in Indonesia. Japan is one of the largest investor countries ranked second from 2007 to 2017 with an investment of US \$ 27.8 million. Japan's investment value is the largest of the five largest investors in Indonesia, namely South Korea, the United States, China and Singapore. Japanese investment is mostly in the manufacturing sector.

As much as 87 percent of Japanese investment in Indonesia is realized in the manufacturing industry sector. To that end, Japanese foreign direct investment has contributed to industrialization in Indonesia, created many jobs, and supported national exports. The contribution of the manufacturing industry (automotive) sub-sector to the non-oil and gas industry sector reached 10.47 percent or the third largest after the food and beverage industry sub-sector. Investment, especially foreign direct investment (FDI) can be one of the factors that influence the economic development of a country, especially Indonesia as a developing country to be able to compete for the progress of the Indonesian.

\section{References}

[1] Directorate General of ASEAN Cooperation. Obstacles and Opportunities for Indonesian Economic Recovery through Investment and Trade Cooperation with ASEAN +3 Dialogue Partners (China-Japan-South Korea. Jakarta: Indonesian Ministry of Foreign Affairs, 2001.

[2] Harvey, David. 2005. A Brief History of Neoliberalism, Oxford, Oxford University Press.

[3] Holsti, K.J. 1992. Politik Internasional Suatu Kerangka Analisis. Bandung: Binacipta.

[4] Jeffry A. Frieden and David A. Lake. 2003. International Political Economy: Perspectives on Global Power and Wealth. Taylor \& Francis e-Library.

[5] M. Sornarajah. 2010. The International Law on Foreign Investment, Cambidge University Press, New York.

[6] Perwita, Anak Agung Banyu \& Yani, Yanyan Mochamad. 2005. Pengantar Ilmu Hubungan Internasional. Bandung : PT Remaja Rosdakarya.

[7] Republic of Indonesia Law Number 25 Year 2007 concerning Investment, Chapter I General Provisions Article 1.

[8] Robert Jackson dan George Sorensen, Introduction to International Relations: Theories and Approaches, fifth edition (Oxford: Oxford University Press, 2013).

[9] Rowland B. F. Pasaribu. Investasi dan Penanaman Modal. Institute for development of economy \& finace, 2012.

[10] Rudy, T. May. 2003. Hubungan Internasional Kontemporer dan Masalah-Masalah Global: Isu, Konsep, Teori dan Paradigma. Bandung: P.T Refika Aditama.

[11] Salim HS \& Budi Sutrisno, Hukum Investasi di Indonesia, Rajawali Pers,2008.

[12] Subandi, Sistem Ekonomi Indonesia, Bandung : Alfabeta, 2009.

[13] Ulbert Silalahi, Metode Penelitian Sosial, Bandung; Refika Aditama, 2009.

[14] Winarno, Budi. "Apakah Kebijakan Publik? dalam Teori dan Proses Kebijakan Publik", Yogyakarta : Media Pressindo, 2002, Page.16.

[15] "Grafik perkembangan investasi asing langsung", 2008-2017, <https://www.ceicdata.com/en/indicator/indonesia/foreign-direct-investment $>$ accessed on december 7, 2017.

[16] "Krisis global penanaman modal asing turun", 2009, < https://finance.detik.com/beritaekonomi-bisnis/d-1286642/krisis-global-penanaman-modal-asing-turun-rp-36-triliun-di2009>, accessed on May 4, 2018. 
[17] Kementrian Perindustrian, "Tiga sektor industri Jepang skala menengah dipacu investasi di Indonesia", 2018, <http://www.kemenperin.go.id/artikel/18299/Tiga-Sektor-IndustriJepang-Skala-Menengah-Dipacu-Investasi-di-Indonesia>, accessed on May 4, 2018.

[18] Kementrian Perindustrian, "Jepang minati sektor infrastruktur dan industri", 2017, <http://www.kemenperin.go.id/artikel/11376/Menperin:-Jepang-Minati-SektorInfrastruktur-dan-Industri> accessed on May 4, 2018.

[19] National Single Windows for Investment BKPM, "Peringkat Realisasi Investasi PMA", 2007-2017 <https://nswi.bkpm.go.id/data_statistik>, accessed on March 18, 2018.

[20] National Single Windows for Investment BKPM, "Perkembangan Realisasi Investasi PMA Jepang di Indonesia", 2007-2017, <https://nswi.bkpm.go.id/data_statistik>, accessed on May 4, 2018.

[21] National Single Windows for Investment BKPM, <https://nswi.bkpm.go.id/tentang_nswi>, accessed on April 20, 2018.

[22] "Pemerintah tingkatkan kerjasama industri dengan Jepang", 2017, $<$ https://katadata.co.id/berita/2017/10/16/pemerintah-tingkatkan-kerja-sama-industridengan-jepang>, accessed on May 4, 2018.

[23] "Pelayanan Terpadu Satu Pintu (PTSP)", <http://nasional.republika.co.id/berita/nasional/badan-pom/15/11/10/nxk6go219pelayanan-terpadu-satu-pintu-di-bkpm>, accessed on April 202018.

[24] "Peraturan Presiden No 97 Tahun 2014", <https://pusdiklat.bkpm.go.id/asset/media/Perpres\%20Nomor\%2097\%20Tahun\%202014.p df>, accessed on April 202018.

[25] Survei Ekonomi EOCD Indonesia, Maret 2015 <https://www.oecd.org/eco/surveys/Overview-Indonesia-2015.pdf >, accessed on december 5, 2017.

[26] Yue, Chia Siow. Hal. 37. in Jurnal Sita Hidriyah, FISIP UI, 2008. <http://lib.ui.ac.id/file?file=digital/118812-T\%2025102-Fluktuasi\%20investasiAnalisis.pdf $>$ accessed on May 4, 2018.

[27] Yuliana Ratnasari, "Indonesia masih menjadi tujuan utama investasi otomatif", 2017, $<$ https://tirto.id/indonesia-masih-jadi-tujuan-utama-investasi-otomotif-cnn2> accessed on May 4, 2018. 